\title{
Dissolution Characteristic of Feldspar in Chang-8 Reservoir, DZ and ZY Region, Xifeng Oilfield of Ordos Basin
}

\author{
Hanlin Liu $^{1, a}$ Fengqin Wang ${ }^{1, b}$ Jin Wang ${ }^{1, c}$ \\ ${ }^{1}$ College of Geosciences and Engineering, Xi'an Shiyou University, Xi'an, 710065
}

\begin{abstract}
Keywords: Ordos Basin, Xifeng Oilfield, Secondary Porosity, Feldspar Dissolution, Dissolution Characteristics
\end{abstract}

\begin{abstract}
Feldspar dissolution phenomenon in Xifeng Oilfield DZ, ZY common areas, feldspar and secondary porosity generated by dissolution study area is an important reservoir of oil and gas reservoir space. This study in order to clarify the situation and development of secondary porosity in the study area, the comprehensive utilization of rock thin section, scanning electron microscopy, $\mathrm{X}$ - ray diffraction analysis of the region's 33 wells 150 rock samples of feldspar dissolution features fine description. Studies show: feldspar dissolution porosity reservoir space, the contribution rate of up to $60 \%$, and feldspar dissolution phenomenon common development in the study area, according to the shape and structure feldspar dissolved pore and feldspar grains can be divided along the periphery of partial dissolution intragranular holes along feldspar twin planes or cleavage seam penetration, dissolving the formed strip, etc., and honeycomb pore structure comprising two or more single; Harbour shape formed by the edge of the arc-shaped tablets dissolved pores the compound dissolved pores..
\end{abstract}

\section{The Basic Characteristics of Studying Region Reservoir Sandstones}

Regional Geological Background and Petrological Characteristics. Xifeng Oilfield is located in Qingyang City, Gansu Province Qingcheng territory, DZ, ZY region in North Shaanxi Slope, Ordos Basin in the southwest and the day ring is connected to the recess. The main oil-bearing strata of Triassic Yanchang Chang 8, is a major controlled by lithology reservoir. Objective region a top layer structure are east to the west of west-dipping monoclinic structure, single-degree slope is generally less than $1^{\circ}$, folds, faults are not development [1]. Delta front is the main reservoir sand bodies in Xifeng Oilfield, reservoir sands are distributed in underwater distributary channel, mouth bar of the local general single sand thickness 5-15m and the largest sand layer thickness $24.6 \mathrm{~m}$ [2]. The average porosity sandstone reservoir is $8.32 \%$ and average permeability 1 . $33 \times 10-3 \mu \mathrm{m} 2$, is a typical low porosity and low permeability reservoirs [3].

According to Zeng Yun Fu Sandstone classification schemes [4], Chang 8 sandstone type mainly lithic feldspathic sandstone and feldspar lithic sandstone and feldspar lithic sandstone which accounts for about $65 \%$ of lithic feldspathic sandstone about $30 \%$, as well as a small amount of lithic sandstone. Debris average content of $86.5 \%$, quartz volume fraction of $16 \%-39 \%$, an average of about 28.31\%; feldspar volume fraction of $9.8 \%-48.5 \%$, an average of about $31.23 \%$; cuttings volume fraction of $18 \%-40.4 \%$, an average of about $26.96 \%$, rich in shallow metamorphic rock cuttings and cuttings is characterized by the eruption. Nearly as quartz, feldspar and lithic sandstone contents described lower compositional maturity; clastic particle size generally less than $0.5 \mathrm{~mm}$, the average of $0.223 \mathrm{~mm}$, fine-grained sandstone, with fine, a small amount of fine-grained.

Pore Characteristics. Xifeng Oilfield DZ, feldspar solution openings ZY Chang 8 Reservoir area mainly by the existing pore types feldspar grains created soluble matrix composition, followed by intergranular pore, cuttings dissolved pore, intergranular pore, solution pore heteroaryl . Among them, $20 \%$ of primary porosity, secondary porosity $78 \%$, in addition to small amounts can effectively improve the tight sandstone reservoir pore connectivity microcracks.

Statistics found that the sheet was observed (Table 1), feldspar dissolved pore, intergranular holes in each sample can be observed, and debris dissolution pore, heteroaryl dissolved pore, intercrystalline pores, microcracks only in some samples appears, pore type combinations mainly 
intergranular pore - solution pass main part of the melting hole, a small pore type. In order to characterize each type of reservoir porosity reservoir space total contribution rate, the proportion of 23 were counted in all kinds of cast thin pores of the total porosity. Statistics show: feldspar solution openings to the total reservoir space, the contribution rate of a minimum of 33\% and a maximum of $86 \%$, with an average of $60 \%$; intergranular hole total reservoir space, the contribution rate of a minimum of $9 \%$ and a maximum of $40 \%$, on average $21 \%$; total dissolved pore cuttings reservoir space minimum contribution rate of 0 and a maximum of $29 \%$, with an average of $10 \%$; heteroaryl dissolved pore space to the total contribution of the reservoir minimum 0 , maximum $13 \%$ average $3 \%$; intergranular hole total reservoir space, the contribution rate of a minimum of 0 and a maximum of $25 \%$, with an average of $5 \%$; microfracture total reservoir space contribution of a minimum of 0 and a maximum of $11 \%$, with an average of $2 \%$. Obviously feldspar dissolution porosity formed in Xifeng Oilfield DZ, ZY secondary pores tight sandstone reservoir area accounted for absolute dominance.

Table 1 Content of each pore of Chang-8 Reservoir, DZ, ZY region, Xifeng Oilfield

\begin{tabular}{|c|c|c|c|c|c|c|c|c|c|c|c|}
\hline No. & $\begin{array}{l}\text { Well } \\
\text { Name }\end{array}$ & Depth/m & Name & $\begin{array}{l}\text { Diment } \\
\text { ion/um }\end{array}$ & Hole/\% & $\begin{array}{l}\text { Feldspar } \\
\text { solution } \\
\text { hole } / \%\end{array}$ & $\begin{array}{l}\text { Cuttings } \\
\text { solution } \\
\text { hole } / \%\end{array}$ & $\begin{array}{l}\text { Heteroaryl } \\
\text { solution } \\
\text { hole } \%\end{array}$ & $\begin{array}{c}\text { Intergran } \\
\text { ular } \\
\text { hole } / \%\end{array}$ & $\begin{array}{l}\text { Microcr } \\
\text { acks } \\
\text { Gap /\% }\end{array}$ & $\begin{array}{l}\text { face } \\
\text { rate } / \%\end{array}$ \\
\hline 1 & X108 & 2110.72 & $\begin{array}{l}\text { Fine - fine-grained } \\
\text { feldspathic sandstone }\end{array}$ & 1 & 1.9 & 0.3 & 0 & 0 & 0 & 3.2 & 1 \\
\hline 2 & X108 & 2110.94 & $\begin{array}{l}\text { Fine-grained lithic } \\
\text { feldspathic sandstone }\end{array}$ & 0.3 & 2.2 & 0.2 & 0.1 & 0.1 & 0 & 2.9 & 0.3 \\
\hline 3 & X108 & 2119.46 & $\begin{array}{l}\text { Fine - fine-grained lithic } \\
\text { feldspathic sandstone }\end{array}$ & 0.2 & 1 & 0 & 0.1 & 0 & 0.1 & 1.4 & 0.2 \\
\hline 4 & X108 & 2121.29 & $\begin{array}{l}\text { Fine - fine-grained } \\
\text { feldspathic sandstone }\end{array}$ & 0.2 & 1.5 & 0.4 & 0 & 0.1 & 0 & 2.2 & 0.2 \\
\hline 5 & X125 & 2099.3 & $\begin{array}{l}\text { Fine - feldspar lithic } \\
\text { sandstone }\end{array}$ & 1 & 1.7 & 0.2 & 0.2 & 0 & 0 & 3.1 & 1 \\
\hline 6 & X125 & 2053.41 & $\begin{array}{l}\text { - The fine-grained lithic } \\
\text { feldspathic sandstone }\end{array}$ & 0.7 & 1.2 & 0.2 & 0 & 0.2 & 0.1 & 2.4 & 0.7 \\
\hline 7 & X125 & 2056.3 & $\begin{array}{l}\text { Fine - fine-grained lithic } \\
\text { feldspathic sandstone }\end{array}$ & 0.4 & 1.8 & 0 & 0.3 & 0.1 & 0 & 2.6 & 0.4 \\
\hline 8 & $\mathrm{X} 125$ & 2065.94 & $\begin{array}{c}\text { Fine - extremely } \\
\text { fine-grained lithic } \\
\text { feldsnathir candstone }\end{array}$ & 0.2 & 1.5 & 0.1 & 0.1 & 0 & 0.1 & 2 & 0.2 \\
\hline 9 & $\mathrm{X} 125$ & 2000.49 & $\begin{array}{l}\text { - The fine-grained lithic } \\
\text { feldspathic sandstone }\end{array}$ & 0.2 & 1 & 0 & 0 & 0.3 & 0 & 1.5 & 0.2 \\
\hline 10 & $\mathrm{X} 125$ & 2146.41 & $\begin{array}{l}\text { - The fine-grained lithic } \\
\text { feldspathic sandstone }\end{array}$ & 0.3 & 1.1 & 0.4 & 0 & 0.3 & 0 & 2.1 & 0.3 \\
\hline 11 & X34 & 2017.63 & $\begin{array}{l}\text { Fine - feldspar lithic } \\
\text { sandstone }\end{array}$ & 0.4 & 0.6 & 0.4 & 0.2 & 0 & 0.2 & 1.8 & 0.4 \\
\hline 12 & X34 & 2019.52 & $\begin{array}{l}\text { Fine - feldspar lithic } \\
\text { sandstone }\end{array}$ & 0.3 & 0.8 & 0.5 & 0 & 0.1 & 0 & 1.7 & 0.3 \\
\hline 13 & X33 & 2021.2 & $\begin{array}{l}\text { - The fine-grained lithic } \\
\text { feldspathic sandstone }\end{array}$ & 0.2 & 1.8 & 0.2 & 0.1 & 0 & 0 & 2.3 & 0.2 \\
\hline 14 & X33 & 2022.57 & $\begin{array}{l}\text { Fine - grained lithic } \\
\text { feldspathic sandstone }\end{array}$ & 0.3 & 1.4 & 0.1 & 0 & 0.1 & 0 & 1.9 & 0.3 \\
\hline 15 & X33 & 2023.7 & $\begin{array}{l}\text { Fine - grained lithic } \\
\text { feldspathic sandstone }\end{array}$ & 0.8 & 1.1 & 0.1 & 0.3 & 0 & 0.1 & 2.4 & 0.8 \\
\hline 16 & X33 & 2024.52 & $\begin{array}{l}\text { Fine - grained lithic } \\
\text { feldspathic sandstone }\end{array}$ & 0.3 & 1.2 & 0 & 0 & 0.2 & 0.1 & 1.8 & 0.3 \\
\hline
\end{tabular}




\begin{tabular}{|c|c|c|c|c|c|c|c|c|c|c|c|}
\hline 17 & X33 & 2091.86 & $\begin{array}{l}\text { Fine - feldspar lithic } \\
\text { sandstone }\end{array}$ & 0.6 & 0.8 & 0.3 & 0.1 & 0.2 & 0 & 2 & 0.6 \\
\hline 18 & X33 & 2094.71 & $\begin{array}{l}\text { Fine - feldspar lithic } \\
\text { sandstone }\end{array}$ & 0.4 & 1 & 0.2 & 0 & 0.1 & 0.1 & 1.8 & 0.4 \\
\hline 19 & X33 & 2096.83 & $\begin{array}{l}\text { The feldspar lithic } \\
\text { sandstone }\end{array}$ & 0.5 & 1.1 & 0.4 & 0 & 0 & 0 & 2 & 0.5 \\
\hline 20 & X33 & 1967.42 & $\begin{array}{l}\text { Fine - grained lithic } \\
\text { feldspathic sandstone }\end{array}$ & 0.4 & 1.1 & 0.7 & 0.1 & 0.8 & 0.1 & 3.2 & 0.4 \\
\hline 21 & X76 & 1983.8 & $\begin{array}{l}\text { Fine - fine-grained lithic } \\
\text { feldspathic sandstone }\end{array}$ & 0.8 & 1.2 & 0 & 0 & 0 & 0.1 & 2.1 & 0.8 \\
\hline 22 & Z26 & 2273.4 & $\begin{array}{c}\text { Clay fine lithic feldspathic } \\
\text { sandstone }\end{array}$ & 0.2 & 1.2 & 0 & 0 & 0 & 0 & 1.4 & 0.2 \\
\hline 23 & Z33 & 2277.6 & $\begin{array}{l}\text { Fine - grained lithic } \\
\text { feldspathic sandstone }\end{array}$ & 0.8 & 1.1 & 0.1 & 0 & 0 & 0 & 2 & 0.8 \\
\hline
\end{tabular}

\section{Feldspar Dissolution Characteristics}

Overall, the research head of stone dissolution extensive development, the performance of acidic medium mineral particles along the twin plane or cleavage seam penetration, dissolution, after expansion to mineral center. Through the typical sampling observation wells in the study area (in Xifeng Oilfield DZ well region X33, X44 Well, X34 Well, X76 length 8 wells feldspathic sandstone, for example), the difference from the feldspar dissolved pore morphology and structure of Chang Shi dissolved pores can be divided into grain edge dissolved pore, intragranular solution pore and dissolved pore complex three categories. Hereinafter, the casting sheet is observed perthite, orthoclase, feldspar, plagioclase feldspar, such as different types of dissolution pore morphology fine description.

Grain edge solution openings refer to feldspar solution openings along the edges formed by partial dissolution. The study area, this dispersion, isolated microporous mostly harbor shape, arc-shaped, often with intergranular hole directly communicated. Can be observed under the microscope plate-feldspar dissolution under the influence of a single mineral particles along the edge of the harbor was like erosion occurs locally, resulting from dissolution of kaolinite filling intergranular pores (Figure 1a). Orthoclase after suffering a stronger degree of corrosion, dissolved pore morphology of the particles with irregular edges half Unicom distribution and dissolution by the grain boundaries also extend toward the center of the particles (1b).

Intragranular holes inside the particles are subjected to secondary feldspar dissolution porosity formation. According to its dissolution shape, can be divided in the isolated state dissolution pores, stepped inside grains dissolve holes in the honeycomb dissolution pores, striped or banded intragranular hole and casting hole and so on. Fig. 1c, feldspar inside the particles are formed along the cleavage seam corrosion isolated, was dispersed within an irregular shaped particle distribution of dissolved pore, solution pore smaller particles account for 5\% to $7 \%$ depending on the region; part of plagioclase stone tablets dissolved in the hole is nearly perpendicular to the two particles along cleavage seam corrosion formed stepped distribution (1d); inner honeycomb dissolution pores due to the strong dissolution, the solution are extremely developed Unicom hole shaped like a honeycomb Fig. 1e feldspar dissolution strong internal particles is about $50 \%$ of the particles partially dissolved sight area, the maximum dissolution pore size of about $80 \mathrm{um}$, is a typical inner honeycomb dissolution pores; striped or banded tablets dissolved particles within the hole is always along the cleavage and development, intragranular hole double crystal micro cracks or joints to form a dissolution of a directivity, and Fig. 1f, plagioclase particles along cleavage always seam corrosion development, striped pore through the entire plagioclase particles; Fig. 1g, the perthite interior of the particle, as a main crystal of pure orthoclase was good continuity of thin strip off and albite crystal with a regular width 2-3um Health delivery particles along the twin joints occur intermittently dissolution, the distribution was interrupted striped dissolution pores better 
directional; Fig. 4h, the feldspar corrosion cracks formed along the broken particles through a strip solution hole. Feldspar casting hole (Fig. 1i, 1j) refers to the interior of the particle was completely feldspar dissolution and formation of intragranular holes having the original shape of the feldspar grains. FIG. 1i, a nearly complete dissolution of feldspar, a small amount of visible holes inside the casting of the original feldspar crystal grain boundaries due to the vertical growth of chlorite membrane adsorption asphalt, was a thick black mantle appeared.

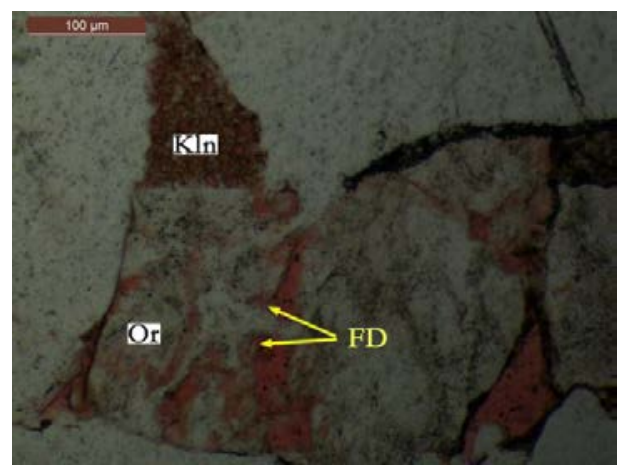

(a)Normal stone along the grain boundaries of local development shaped harbor dissolved pore, X76 well $2023.7 \mathrm{~m}$, casting, single polarization

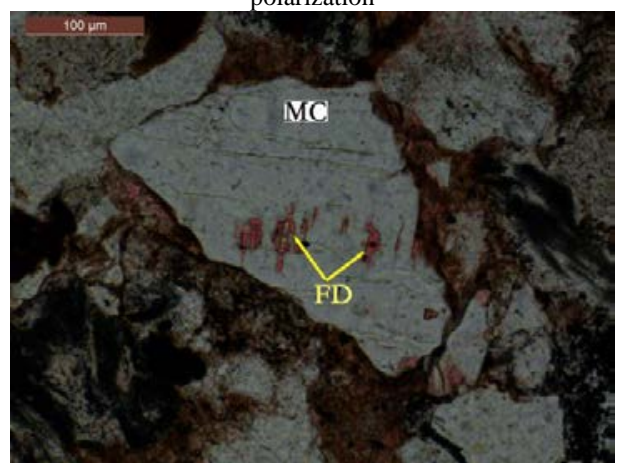

(c)Feldspar particles inside isolated irregular dissolution pores, X76 Well, $2023.7 \mathrm{~m}$, casting, single polarization

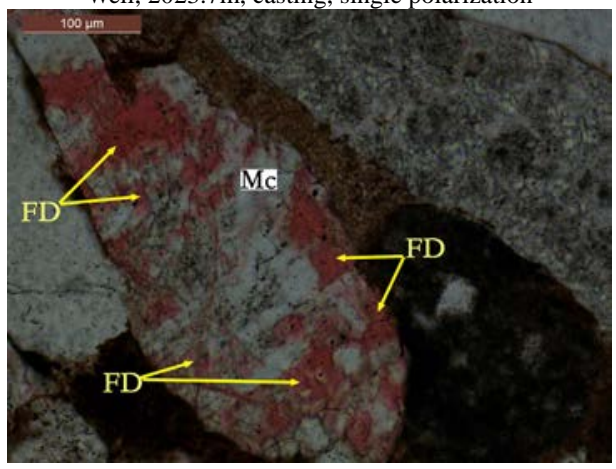

(e)Feldspar dissolution dissolved form a honeycomb hole, X76 Well, 2023.7m, casting, single polarization

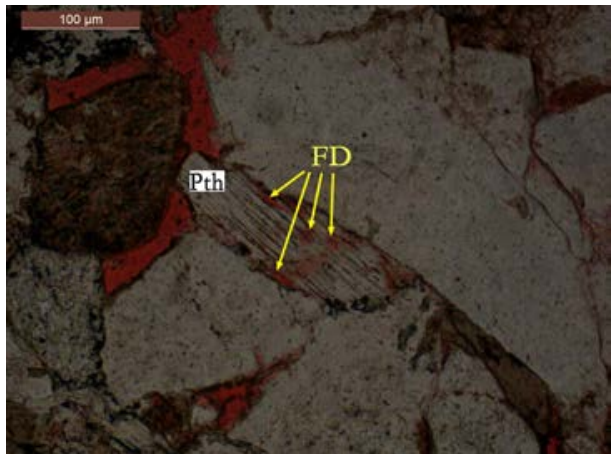

(g) Perthite along the twin joints intermittent erosion occurs, creating intermittent strip dissolved pore, X34 Well, 2012.5m, casting, single

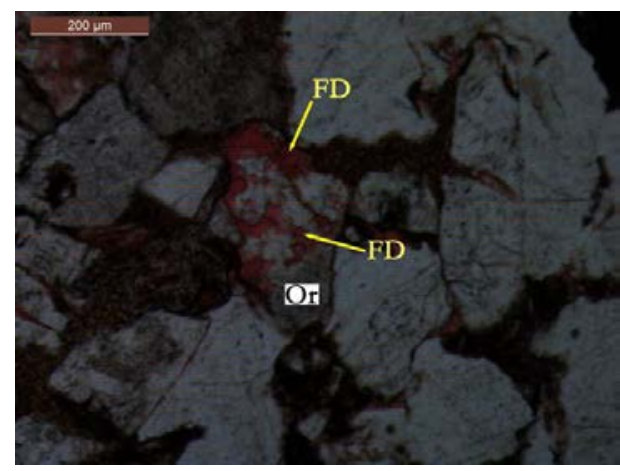

(b)Stone tablets dissolve properly margin of stomatal development, X76 well $2023.7 \mathrm{~m}$, casting, single polarization

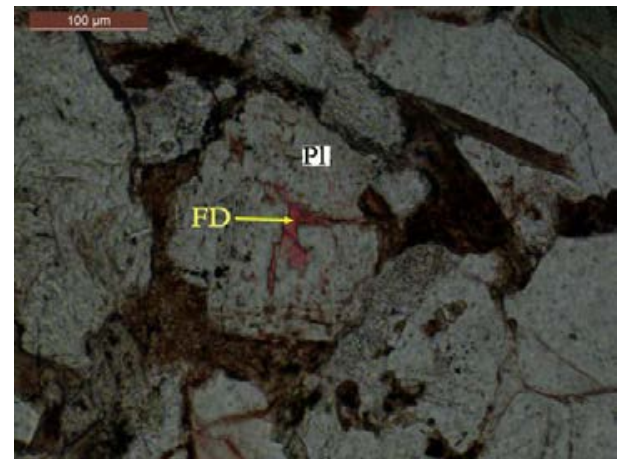

(d)Within plagioclase dissolution pores stepped, X33 well, 2012.5m,

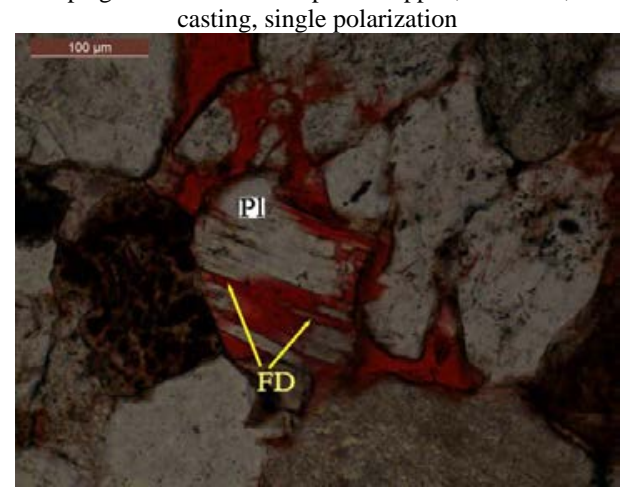

(f)Plagioclase along cleavage pattern has been formed by erosion strip dissolved pore, X44 Well, 2091.86m, casting, single

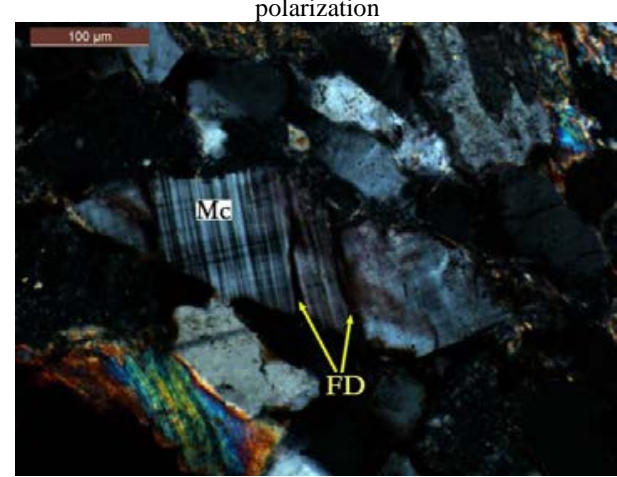

(h)Plagioclase compression fracture particles along broken crack corrosion, forming banded dissolved pore, X33 Well, 2012.5m, 


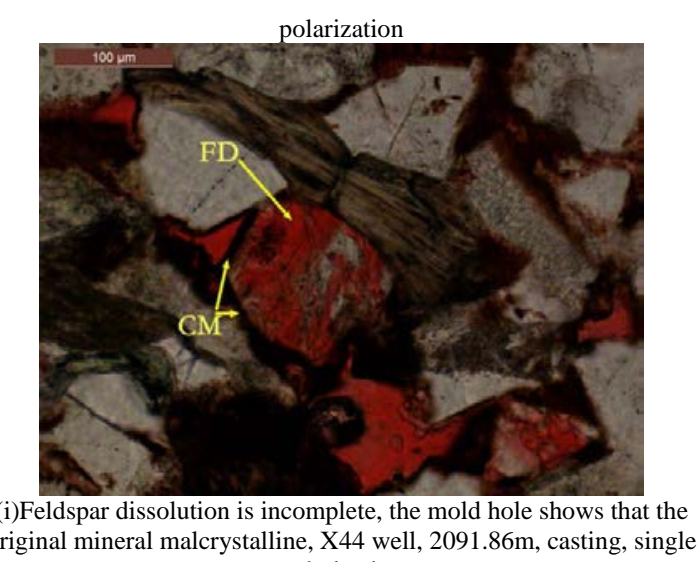

original mineral malcrystalline, X44 well, $2091.86 \mathrm{~m}$, castir

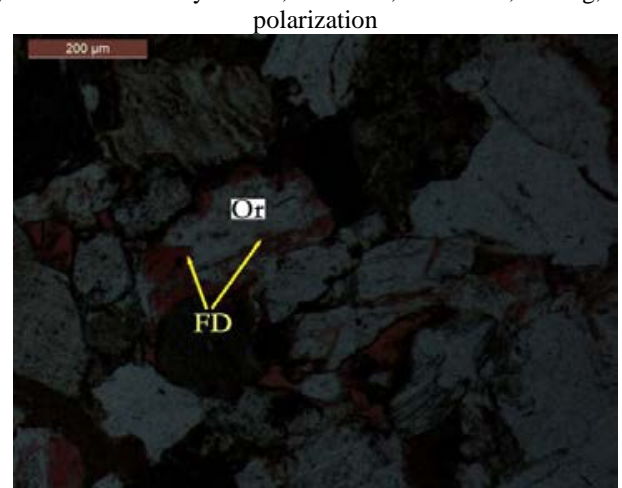

(k)Feldspar dissolved pore complex, X34 Well, 2019.52m, casting, single polarization
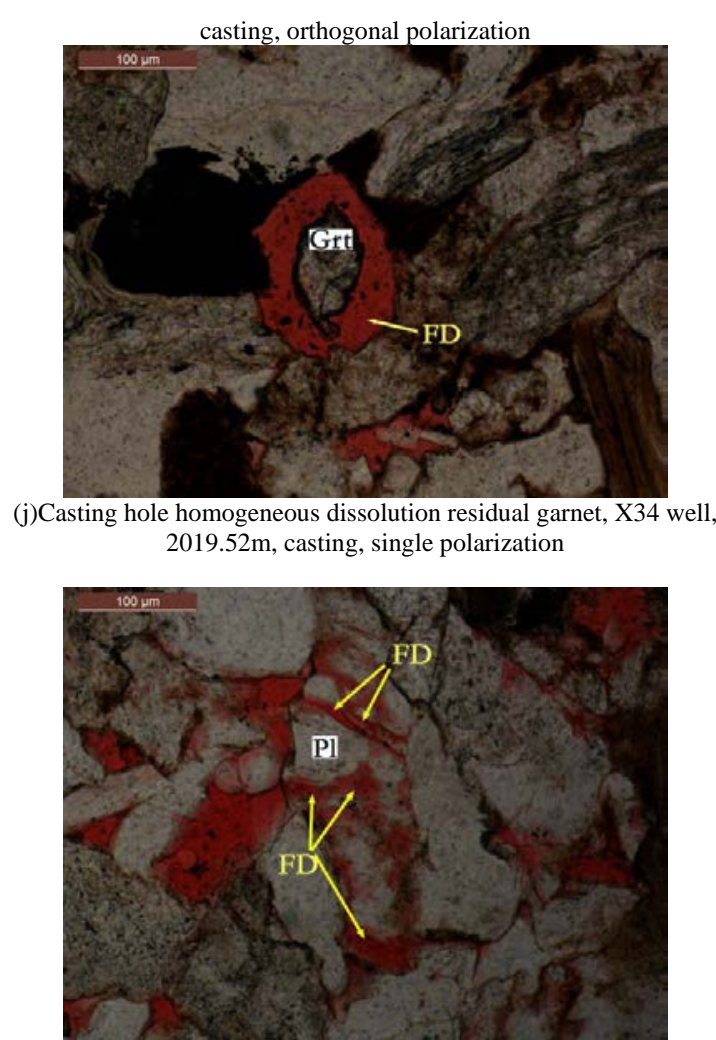

(l)Feldspar dissolved pore complex, X34 Well, 2019.52m, casting, single polarization

Fig.1 Characteristics of feldspar dissolution pores of Chang-8 Reservoir, DZ 、ZY region, Xifeng Oilfield

(Note: FD- feldspar secondary porosity, CM- chlorite clay crystal sets, Pth- perthite, Kfs- feldspar, Mc- feldspar, Pl- plagioclase, Or- orthoclase, Kln - kaolinite, Grt- garnet)

Feldspar solution openings composite refers feldspar grains after the dissolution of both the pore structure of two or more types. Fig. 1k, the particles of the peripheral edge of not only the development of arcuate dissolved pore isolated distribution within the particles visible single along cleavage seam corrosion formed with dissolution pores; Fig. 1l, the striped grain within the feldspar grains along broken crack corrosion formation edge tablets dissolved pore solution pores and irregular distribution than in the development of China Unicom. Hole in the compound dissolved feldspar and other alkali feldspar in common, which often accounts for particle erosion area depending on an area of $50 \%$ or higher.

With the dissolution of feldspar particles, can produce large amounts of secondary dissolution pores and corrosion by-products (kaolinite and authigenic illite). Microscope, microscopic characteristics showed that if the feldspar dissolution is weak, then the feldspar secondary porosity content is low, dissolution byproduct content is low, if the feldspar dissolution are strong, feldspar secondary porosity content, while in the vicinity of secondary porosity of primary porosity precipitated a lot of spontaneous dissolution byproducts [7].

\section{The Main Conclusions}

(1) Xifeng Oilfield DZ, feldspar solution openings ZY Chang 8 Reservoir area mainly by the existing pore types feldspar soluble matrix particle erosion formation cuttings dissolved pore composition, followed by intergranular pore, intercrystalline pores, in addition there is a very small amount can improve the tight sandstone reservoir pore connectivity microcracks. Among them, the development of a wide range of feldspar dissolved pore, feldspar dissolved pore reservoir reservoir space, the contribution rate of up to $60 \%$.

(2) organic evolution, a large number of organic acids is discharged, so that the study area different feldspar dissolution significant difference, according to the shape and structure of the feldspar dissolved pores: in the main development granulocyte zone dissolved pore, intergranular 
dissolved pore and complex solution hole. Study area edge tablets dissolved feldspar grains along the edge of the hole localized corrosion formed scattered, isolated harbor shape, arc-shaped pores, often associated with intergranular hole directly communicated. Intragranular pore shape according to its dissolution, can be divided into isolated state dissolution pores, stepped inside the grains dissolve holes in the honeycomb dissolution pores, inner stripe or strip dissolution pores and casting hole and so on. Feldspar dissolved pore complex in feldspar and other alkali feldspar in common, which often accounts for particle erosion area depending on an area of 50\% or higher.

\section{References}

[1] Jiang Hong-xia , Wu Ya-sheng , Luo Xiao-rong et al. Diagenesis and controls on the physical properties of the Triassic Chang-8 oil reservoirs in the south-central part of the Ordos Basin [J]. Sedimentary Geology and Tethyan Geology, 2007, 27(1):54-61.

[2] Ye Chenglin,Zhang Chunsheng, Wang Danfu. Characteristics in Layer Heteroceneity in Chang 81 Reservoir, Dongzhi Region, Xifeng Oilfield[J]. Geological Survey and Research

[3] He Zixin,He Jing. Atlas of Mesozoic Reservoirs in Ordos Basin[M]. PETROLEUM INDUSTRY PRESS ,2004: 184-185

[3] Liu Linyu,Cao Qing,Liu Yiqun et al. Chang 81Sandstone Diagenesis and the Influence on Chang 81Reservoir

of south Area of Baima, Ordos Basin[M]. ACTA GEOLOGICA SINICA,2006,80(5): 712-717

[4] Tian Jianfeng, Gao Yongli, Zhang Pengbo et al. Genesis of illite in Chang 7 tight oil reservoir in Heshui area, Ordos Basin[J]. Oil \& Gas Geology,2103,34(5): 700-707 